\title{
The Effect of Prayer on Patients' Health: Systematic Literature Review
}

\author{
Talita Prado Simão ${ }^{1, *}$, Sílvia Caldeira ${ }^{2, \dagger}$ and Emilia Campos de Carvalho ${ }^{1, \dagger}$ \\ Received: 1 December 2015; Accepted: 12 January 2016; Published: 21 January 2016 \\ Academic Editors: Fiona Timmins and Wilf McSherry \\ 1 Ribeirão Preto College of Nursing_EERP-USP, University of São Paulo, São Paulo, Brazil; \\ ecdcava@eerp.usp.br \\ 2 School of Nursing, Centre for Interdisciplinary Research in Health, Institute of Health Sciences, \\ Universidade Católica Portuguesa, Palma de Cima, 1649-023 Lisboa, Portugal; scaldeira@ics.lisboa.ucp.pt \\ * Correspondence: tapsimao@usp.br; Tel.: +55-163-315-3475; Fax: +55-163-315-0518 \\ + These authors contributed equally to this work.
}

\begin{abstract}
There is increasing interest regarding prayer in healthcare. Prayer is an activity related to spirituality and religion. Positive outcomes have been identified regarding spirituality in health. This study aims to investigate the effects on patients' health of using prayer. A systematic literature review was conducted in May 2015 and updated in November 2015. Electronic and international databases were searched and the inclusion criteria were based on PICOS: (Population) patients of any age and any clinical situation, (Intervention) all types of prayer, (Comparison) ordinary care, (Outcomes) any health change, (Study type) randomized clinical trials. Neither timeframe nor limitation in language were considered. A total of 92 papers were identified and 12 were included in the review. Prayer was considered a positive factor in seven studies, and several positive effects of prayer on health were identified: reducing the anxiety of mothers of children with cancer; reducing the level of concern of the participants who believe in a solution to their problem; and providing for the improved physical functioning of patients who believe in prayer. Prayer is a non-pharmacological intervention and resource, and should be included in the nursing holistic care aimed at patients' well-being.
\end{abstract}

Keywords: faith healing; religion; health; clinical trial; randomized controlled trial

\section{Introduction}

Health is deemed valuable to human life. The WHO [1] definition of health comprises physical, psychological, and spiritual factors as well as social well-being, and is based on the harmony between several factors, such as values, culture, age, social background, and the philosophical and religious beliefs of each person [2].

Religion is defined as a system of symbolic elements and rituals through which people can connect with the divine or the sacred [3,4]. Spirituality is a dimension related to finding meaning in life and answers to fundamental aspects of life through sacred and transcendent experiences [5], which are able to provide health benefits.

Spirituality and religion are positively associated with physical health [6]. The literature suggests beliefs and religious practices are associated with: improved physical and mental health outcomes; having a beneficial effect on immune function; welfare; higher levels of satisfaction with life; hope; optimism; lower rates of anxiety and depression [7].

Each person uses cognitive and behavioural strategies, in accordance with their religious beliefs and how they view the meaning of their life, to overcome adverse situations in life, especially those involving health. We highlight prayer, among these. The word "prayer" has two different meanings, based on the Latin origin prex, precis. It means supplication, the vows and wishes of a superior being 
that transcends the material space [8]. Prayer is considered a particularly important intervention in spiritual care for those in suffering [9]. Several types of prayer are defined in literature. The most used forms are intercessory prayer and petition prayer. In intercessory prayer, there is no direct contact or involvement between the individuals who are begging (intercessors) and those who are the target of the prayer. Petition prayer, on the other hand, is asking for help for oneself [10].

Praying is a spiritual activity often used by patients, which seems to facilitate the health/disease transition process and promote well-being [11]. Prayer is much more than just a resource for promoting "positive religious/spiritual coping with the situation". It also promotes hope by providing a connection with a sacred and self-transcending dimension [12]. It is way to connect with self, with others and with the sacred [13]. Although it is common practice in different doctrines, it only began to be studied as an important tool in health [14] in 1980, as a source of comfort and hope, among other virtues [15].

The scientific community recognises prayer as a complementary therapy and a therapeutic intervention within holistic assistance and, whether it is intercessory or petition, prayer may be included in healthcare in several contexts. This is because it helps to solve crises and personal issues of the elderly, reduces the anxiety of patients undergoing chemotherapy, and improves the spiritual well-being of cancer patients [16-18]. However, many questions remain concerning evidence of the real benefits of prayer on patients' health.

This study aims to explore the contribution of prayer to the health/disease process and to promote the integration of prayer in holistic healthcare assistance, by investigating the effects of using prayer on patients' health, considering only randomized clinical trials.

\section{Method}

A systematic literature review was conducted in May 2015 and updated in November 2015 [19,20].

A protocol was defined to plan the systematic review and included the research question, the inclusion and exclusion criteria, the search strategy and databases, the data collection instruments and methods and the criteria for the analysis of the results. The review question was: "What are the effects of prayer on patients' health?" The PICOS strategy considered was as follows [21]: (Population) patients of any age and any clinical situation, (Intervention) all types of prayer, (Comparison) ordinary care, (Outcomes) any health change, (Study type) randomized clinical trials (RCT), according to the outcome included in research question related to the effect of the prayer.

Electronic and international databases were searched: Cumulative Index to Nursing and Allied Health Literature (CINAHL), Academic Search Premier, Literatura Latino-Americana e do Caribe em Ciências da Saúde [Latin-American and Caribbean Health Sciences Literature] (LILACS), Medline, Scientific Electronic Library Online (SciELO), and The Cochrane Library. The search strategy was "prayer" AND "clinical trial". Such a combination was chosen because it is broad, considering the focus of interest, and was limited to title, considering the specificity of the theme and the type of study (RCT). Neither timeframe nor limitation to language were considered.

The search and the analysis of the papers identified in the first search was conducted independently by two researchers. Data were organised in tables containing: year, author, journal, sample characteristics (experimental group and control group), assessment method, main outcomes, and the score according to the Jadad criteria. The purpose of this instrument is to verify the quality of the clinical data reported in papers, such as the blinding characteristics. The score ranges from 0 to 5 , and results equal or higher than three indicate consistent studies [22].

\section{Results}

A total of 92 papers were identified. Fifteen duplicates were removed, and 65 were excluded as they did not meet the inclusion criteria. The final sample for analysis was composed of 12 papers (Figure 1 ). 


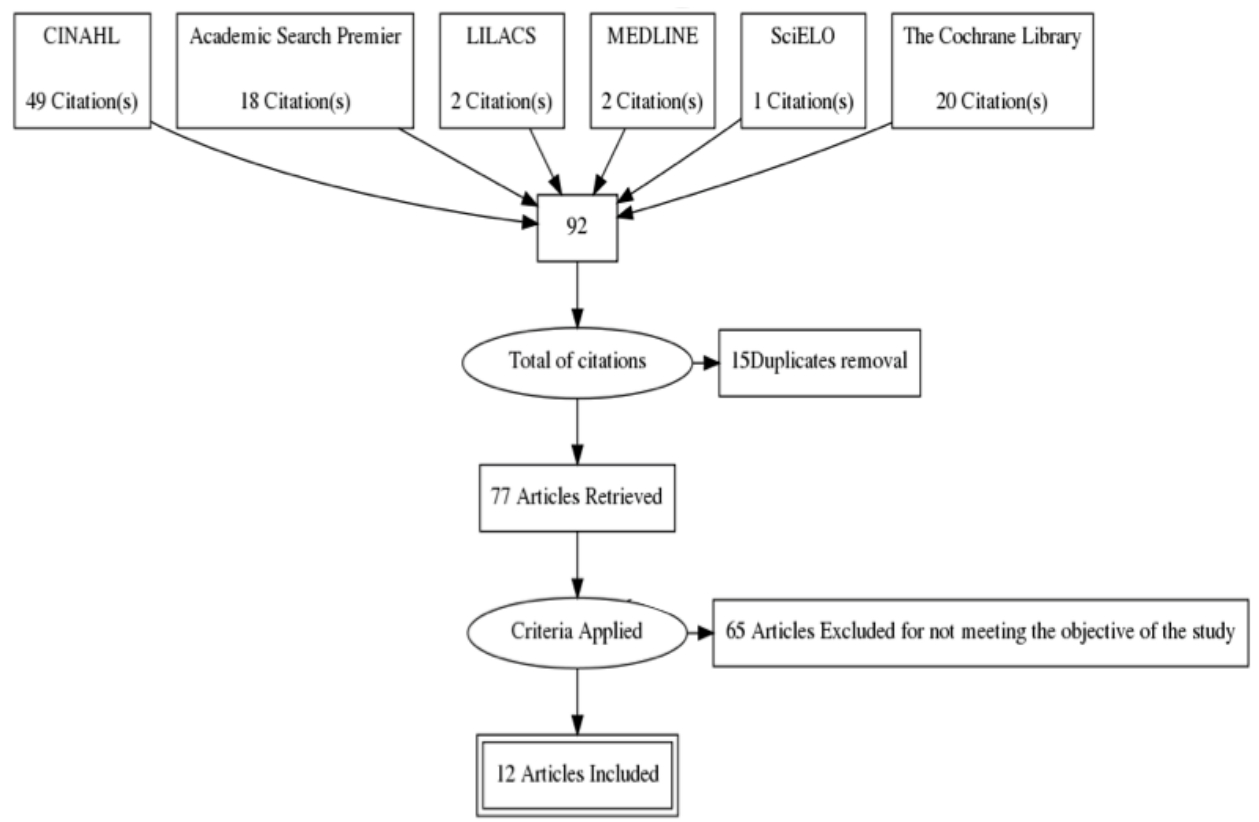

Figure 1. Study selection process.

Seven studies had been conducted in the USA [23-29], one in South Korea [30], one in Israel [31], one in the UK [32] and two did not identify the origin [33,34]. The papers had been published in several health journals, two of which related to complementary and alternative practices [22,25]. Six articles had been published over the past decade [23-25,27,33,34] and only two in the 1990s [28,32].

With regard to the type of prayer, two studies made use of petition prayer [24,34] and 10 of intercessory prayer [23,25-33]. There was a study that associated other therapies with intercessory prayer, such as music, image guidance and therapeutic touch [25].

In relation to population and outcomes, two articles analysed the anxiety of mothers of children with cancer [34]. Another study investigated anxiety and depression in patients with psychological disorders [24]. Four analysed adverse events in patients with cardiac disorders [25,27-29], two of which included patients undergoing cardiac surgery [25,27]. Two had pregnancy as the research focus: one investigated the success of in vitro fertilization [30] and the other was related to pregnancy and labour [33]. Another study evaluated the effect of prayer on the health of people with acquired immunodeficiency syndrome [23]. One study analysed the emotional/spiritual concerns of adult patients regarding their illness [26]. One study evaluated patients with bloodstream infections regarding the number of deaths, length of stay in hospital and duration of hyperthermia [31]. One study investigated the clinical status and attitude of patients with psychological or rheumatic disease [32].

The results show that prayer was considered a positive factor in seven of the 12 studies $[24,26,28,30-32,34]$. Positive outcomes comprised the reduction of anxiety of mothers of children with cancer, as well as a decrease in the level of concern of the participants who believe there is a solution to their problem, and the improved physical functioning of individuals who believe in prayer (Table 1).

The majority of the studies focused on one daily prayer or more than one prayer per day $[23,24,26-28,32,34]$, during a research period equal to or less than one month [23,25-28,30,33,34]. In two studies, the intercessors had different religious backgrounds (Christians, Protestants, Jews, Buddhists and Muslims) [25,27].

As regards the methodological quality of the trials included in this review, 11 scored higher than 3 in the Jadad criteria. This instrument includes the participant blinding criteria, but in one of the studies analysed the participants also performed the intervention and so, because of that, this criteria was not followed in that instance [34]. 
Table 1. Synthesis of the research papers included in the review.

\begin{tabular}{|c|c|c|c|c|}
\hline \multirow{2}{*}{$\begin{array}{c}\text { Paper } \\
\text { Paper } 1[22]\end{array}$} & \multicolumn{2}{|c|}{ Sample } & \multirow[b]{2}{*}{$\begin{array}{c}\text { Assessment (A)/Intervention (I) } \\
\text { (A) } \\
\text {-Generic data (number of clinic visits, consultations and hospitalizations); } \\
\text {-Mood (Profile of Mood States); } \\
\text {-Quality of life (Functional Assessment to Human } \\
\text { Immunodeficiency/Virus-FAIN version 4); } \\
\text {-Illness severity; } \\
\text {-CD4 + T lymphocyte count; } \\
\text {-Triglycerides, cholesterol, high-density lipoprotein (HDL), alanine } \\
\text { transaminase (ALT), aspartainine transaminase (AST), bilirubin, alkaline } \\
\text { phosphatase, indicators of toxicity antiretroviral therapy. } \\
\text { (I) } \\
\text {-Intercessory prayer was performed for one hour every day during } 20 \\
\text { weeks. The intercessor imagined the patient and asked for them to be cured. } \\
\text {-One IG with Intercessor Nurse Healers; } \\
\text {-One IG with Intercessor Professional Healers. }\end{array}$} & \multirow{2}{*}{$\begin{array}{l}\text { Outcomes } \\
\text {-After } 6 \text { months there was a reduction in the absolute count of } \\
\text { CD4 + lymphocyte in the IG }(p=0.02 \text { ) compared to the CG; } \\
\text {-After } 12 \text { months triglyceride levels had a reduction in GI } \\
\text { compared to CG }(-82.6 \mathrm{mg} / \mathrm{dL} \text { vs. } 8.6 \mathrm{mg} / \mathrm{dL}, p=0.028) \text {. }\end{array}$} \\
\hline & $\begin{array}{c}\text { IG } \\
\text { Acquired immunodeficiency } \\
\text { syndrome patients: } 40 \\
\text { Acquired immunodeficiency } \\
\text { syndrome patients: } 38\end{array}$ & $\begin{array}{c}\text { CG } \\
\text { Acquired immunodeficiency } \\
\text { syndrome patients: } 39\end{array}$ & & \\
\hline Paper 2 [23] & $\begin{array}{l}\text { Patients with depressive disorders } \\
\text { and anxiety: } 27\end{array}$ & $\begin{array}{l}\text { Patients with depressive disorders } \\
\text { and anxiety: } 36\end{array}$ & $\begin{array}{c}\text { (A) } \\
\text {-Hamilton Rating Scales for Depression and Anxiety; } \\
\text {-Life Orientation Test; } \\
\text {-Daily Spiritual Experiences Scale; } \\
\text {-Cortisol; } \\
\text { (I) } \\
\text {-Six weeks of prayer; } \\
\text { remaisted 90 minutes; and } 60 \text { minutes for the } \\
\text {-First intercessory prayersions; } \\
\text {-Intervention by a minister trained in healing prayer through Christian } \\
\text { Healing Ministries. Based on the patient's history the minister used a } \\
\text { secular prayer (asking for pain relief and blessings); } \\
\text {-The minister was often with the participant during the intervention. }\end{array}$ & $\begin{array}{l}\text {-IG showed significant improvement in anxiety and depression, } \\
\text { as well as more daily spiritual experiences and optimism } \\
\text { compared to } C G(p<0.01) ; \\
\text {-Patients kept these results during one month after receiving } \\
\text { the intervention }(p<0.01) \text {. }\end{array}$ \\
\hline Paper 3 [24] & $\begin{array}{l}371 \text { Patients undergoing } \\
\text { percutaneous coronary intervention } \\
\text { or elective catheterisation } \\
189 \text { received prayer, music, image } \\
\text { guidance and healing touch; } \\
182 \text { only received prayer. }\end{array}$ & $\begin{array}{l}377 \text { did not receive prayer; } 185 \text { had } \\
\text { the music, image and touch } \\
\text { intervention, and } 192 \text { received only } \\
\text { regular care }\end{array}$ & $\begin{array}{c}\text { (A) } \\
\text {-Presence of adverse cardiovascular events readmission and/or death, at } \\
\text { hospital discharge and six months afterwards; } \\
\text {-Critical cardiovascular events such as a new myocardial infarction assessed } \\
\text { by electrocardiogram or increased creatine phosphokinase. } \\
\text { (I) } \\
\text {-The } 12 \text { prayer groups involving Christians, Muslims, Jews and Buddhists } \\
\text { were informed of the patients' name, age and health condition. } \\
\text {-Each group was responsible for the content, schedule and duration of } \\
\text { prayers (ranging from } 5 \text { to } 30 \text { days). }\end{array}$ & $\begin{array}{l}\text {-The unique use of prayer had no significant outcome on the } \\
\text { clinical evolution of the groups, and the Odd Ratio was } 0.97 \\
(0.77-1.24) p=0.8351 \text {, at confidence interval of } 95 \% ; \\
\text {-After six months, death and readmission was } 0.93(0.72-1.19) \\
p=0.5220 \text {, major cardiovascular event } 0.85(0.63-1.14) 0.2785 \\
\text { and death } 1.13(0.53-2.4) p=0.7531 .\end{array}$ \\
\hline
\end{tabular}


Table 1. Cont.

\begin{tabular}{|c|c|c|c|c|}
\hline Paper & \multicolumn{2}{|c|}{ Sample } & Assessment (A)/Intervention (I) & Outcomes \\
\hline Paper 4 [25] & $\begin{array}{l}\text { Men and women aged } 18-88 \text { years } \\
\text { who attended the Presbyterian } \\
\text { Church: } 45\end{array}$ & $\begin{array}{c}\text { Men and women aged 18-88 years } \\
\text { who attended the Presbyterian } \\
\text { Church: } 41\end{array}$ & $\begin{array}{l}\text { (A) } \\
\text {-Rating scales to assess prayers outcomes (1-4 and 1-5); } \\
\text {-Medical Outcomes Study SF-20 (components: physical functioning, pain } \\
\text { and mental health). } \\
\text {-All data were collected before and after the intervention. } \\
\text { (I) } \\
-12 \text { intercessor volunteers, who received the patient's first name and a } \\
\text { written summary of their concerns and problems. They recorded how often } \\
\text { and how long they prayed, and whether they were or not tusing a script } \\
\text { about what was asked in prayer. Each group was asked to pray once a day } \\
\text { for a month, targeting at least one or two participants. The average was } \\
\text { twice a day and a duration of } 3 \text { minutes. }\end{array}$ & $\begin{array}{l}\text {-Prayer decreases the level of concern of the participants who } \\
\text { believe in a solution to their problem; } \\
\text {-Prayer was related to better physical functioning }(p<0.002) \text { for } \\
\text { participants who believe in prayer. }\end{array}$ \\
\hline Paper 5 [26] & $\begin{array}{c}\text { Patients undergoing coronary } \\
\text { artery bypass } \\
601 \text { were aware they were receiving } \\
\text { the intervention } \\
604 \text { did not know if they were or } \\
\text { were not receiving the intervention }\end{array}$ & $\begin{array}{l}\text { Patients undergoing coronary } \\
\text { artery bypass } \\
597 \text { did not know if they were or } \\
\text { were not receiving the intervention }\end{array}$ & $\begin{array}{c}\text {-Postoperative complication among } 30 \text { (Society of Thoracic Surgeons Adult } \\
\text { Cardiac Surgery Database); } \\
\text {-Any major event (defined by the New York State Cardiac Surgery } \\
\text { Reporting System); } \\
\text {-30-day mortality. } \\
\text { (I) } \\
\text {-Three groups (two Catholic and one Protestant) which had access to a list } \\
\text { of patients; } \\
\text {-The prayer was said at 0:00 pm the day before the surgery, and lasted for } 14 \\
\text { consecutive days. }\end{array}$ & $\begin{array}{c}-52 \% \text { of patients of IG who were not aware if they were } \\
\text { receiving prayers (315/604) had complications compared to } \\
51 \%(304 / 597) \text { of patients of CG (relative risk 1.02, } \\
95 \% \text { CI 0.92-1.15); } \\
-59 \% \text { of patients of IG who knew they were receiving prayer } \\
\text { had complications (352/601) compared to patients of IG who } \\
\text { did not know if they were receiving intercessory prayer } \\
\text { (relative risk 1.14, } 95 \% \text { CI 1.02-1.28); } \\
\text {-30-day mortality after surgery was similar for the three groups. }\end{array}$ \\
\hline Paper 6 [27] & Patients admitted to the CCU: 484 & Patients admitted to the CCU: 529 & $\begin{array}{c}\text { (A) } \\
\text {-Collected information; } \\
\text {-Comorbidities; } \\
\text {-Length of stay in CCU; } \\
\text {-Clinical outcomes. } \\
\text { (I) } \\
\text { - } 15 \text { teams with five intercessors who were given the participants' first name; } \\
\text { - Daily intercessory prayer over a four-week period. }\end{array}$ & $\begin{array}{c}\text {-Patients of IG had lower weighted average when compared to } \\
\text { CG }(6.35 \pm 7.13 \text { vs. } 0.26 \pm 0.27 ; p=0.04) \text { and unweighted } \\
\text { average ( } 2.7 \pm 0.1 \text { vs. } 3.0 \pm 0.1 ; p=0.04) \text { considering the days } \\
\text { patients were in Coronary Care Unit; } \\
\text {-The length of stay in CCU was similar. }\end{array}$ \\
\hline
\end{tabular}


Table 1. Cont

\begin{tabular}{|c|c|c|c|c|}
\hline Paper & & & Assessment (A)/Intervention (I) & Outcomes \\
\hline Paper 7 [28] & $\begin{array}{l}\text { Patients with cardiovascular disease } \\
\text { after hospital discharge: } 400\end{array}$ & $\begin{array}{l}\text { Patients with cardiovascular disease } \\
\text { after hospital discharge: } 349\end{array}$ & $\begin{array}{c}\text { (A) } \\
\text {-Death, heart failure, readmission or emergency department attendance, and } \\
\text { coronary revascularization. } \\
\text {-Three groups of patients were clustered according to risk: high risk (age = } \\
70 \text { years, diabetes mellitus, previous mocardial infarction, cerebrovascular } \\
\text { disease or peripheral vascular disease), and low risk (no risk factors). } \\
\text { (I) } \\
\text {-Intercessory prayer was held once a week for } 26 \text { weeks; } \\
\text {-215 intercessors were divided into five groups ranging from } 1 \text { to } 65 ; \\
\text {-Intercessor groups prayed for 1-100 patients who were randomly } \\
\text { distributed; } \\
\text {-Intercessors were provided with the name, age, gender, diagnosis, and } \\
\text { patients' health status. }\end{array}$ & 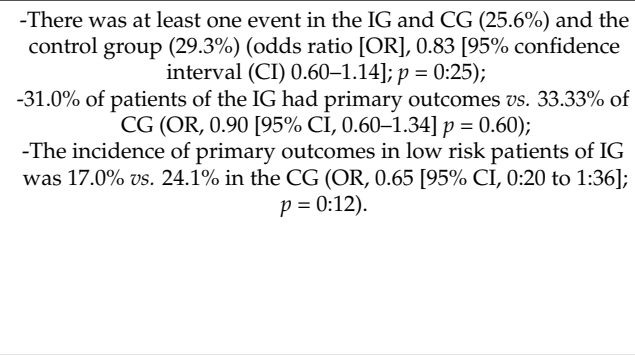 \\
\hline Paper 8 [29] & IVF Women: 88 & IVF Women: 81 & $\begin{array}{c}\text { (A) } \\
\text {-Pregnancy rate; } \\
\text {-Implantation rate; } \\
\text {-Number of babies. } \\
\text { (I) } \\
\text { weatms } \\
\text {-Intercessory prayer five days after treaning and lasted for three } \\
\text {-Each prayer group consisted of } 3 \text { to } 13 \text { intercessors that prayed for five } \\
\text { patients asking for an increased pregnancy rate. }\end{array}$ & $\begin{array}{l}\text {-IG had a higher pregnancy rate compared to CG (46.6\% vs. } \\
22.2 \%, p<0.001) ; \\
\text {-IG had a higher implantation rate }(16.3 \% \text { vs. } 8 \%, p=0.0005) \\
\text { and multiple babies }(17 \% \text { vs. } 4.9 \%, p=0.0126) .\end{array}$ \\
\hline Paper 9 [30] & $\begin{array}{l}\text { Patients with bloodstream } \\
\text { infection:1961 }\end{array}$ & $\begin{array}{l}\text { Patients with bloodstream } \\
\text { infection: } 1702\end{array}$ & $\begin{array}{l}\text { (A) } \\
\text {-Number of deaths; } \\
\text {-Length of stay in hospital from day one of a positive blood-culture; } \\
\text {-Length of hyperthermia (temperature }>37.5^{\circ} \mathrm{C} \text { ). } \\
\text { (I) } \\
\text {-Intercessors had a list with the first names of the patients of the IG. They } \\
\text { asked for their well-being and full recovery. }\end{array}$ & $\begin{array}{l}\text {-IG had lower number of deaths }[28.1 \%(475 / 1691)] \text { compared } \\
\text { to the CG [30.2\% (514/1702) }(p=0.4) \\
\text {-Regarding the length of stay in hospital and duration of fever, } \\
\text { IG had significantly fewer events than the CG }(p=0.01 \text { and } \\
\qquad p=0.04 \text {, respectively). }\end{array}$ \\
\hline
\end{tabular}


Table 1. Cont.

\begin{tabular}{|c|c|c|c|c|}
\hline Paper & \multicolumn{2}{|c|}{ Sample } & Assessment (A)/Intervention (I) & Outcomes \\
\hline Paper 10 [31] & $\begin{array}{l}\text { Patients with rheumatic or } \\
\text { psychological disease: } 24\end{array}$ & $\begin{array}{l}\text { Patients with rheumatic or } \\
\text { psychological disease: } 24\end{array}$ & $\begin{array}{c}\text { (A) } \\
\text {-Clinical State Scale; } \\
\text {-Attitude State Scale; } \\
\text { (I) } \\
\text { (Two times in consultationt } 6 \text { to } 8 \text { months). } \\
\text {-Six groups with } 19 \text { intercessors who were given participants' first name; } \\
\text {-Participation of all the 19 people involved in prayer, two as lone } \\
\text { individuals and the rest were divided into } 4 \text { groups: } \\
\text {-The group prayers were held once every two weeks, for one hour; } \\
\text {-Individual prayer was conducted every day for 15 minutes; } \\
\text {-Each patient received an average of 15 hours of prayer for a minimum } \\
\text { period of } 6 \text { months. } \\
\text { The prayer method used was silent meditation in which the intercessor } \\
\text { focused all his attention on a short phrase that expresses some positive } \\
\text { affirmation about God, which is most often obtained from the Bible. }\end{array}$ & $\begin{array}{l}\text { Both instruments had similar results, but patients in IG had } \\
\text { better results compared to the CG. }\end{array}$ \\
\hline Paper 11 [32] & $\begin{array}{l}\text { Pregnant women with gestational } \\
\text { age of } 37 \text { weeks: } 281\end{array}$ & $\begin{array}{l}\text { Pregnant women with gestational } \\
\text { age of } 37 \text { weeks: } 285\end{array}$ & $\begin{array}{c}\text { (A) } \\
\text {-Type of delivery; } \\
\text {-Apgar score; } \\
\text {-Birth weight and macrossomy. } \\
\text {-Age; } \\
\text {-Gestational age; } \\
\text {-Associated diseases; } \\
\text {-Belief in God and religion. } \\
\text { (All variables were dichotomized). } \\
\text { (I) } \\
\text {-The intercessors group was composed of six women, coordinated by a } \\
\text { theologian. They asked for good delivery and health of the newborn, over } \\
\text { nine consecutive days. }\end{array}$ & $\begin{array}{c}\text {-Both IG and CG had a similar number of serious adverse } \\
\text { events: spontaneous abortion }(p=0.53) \text {, intrauterine foetal } \\
\text { death and }(p=0.30) \text {, low Apgar score }(p=0.34) \text {, preterm birth } \\
(p=0.33) \text {, small size for gestational age }(p=0.62) \text {, macrossomy } \\
(p=0.09) \text {, caesarean delivery }(p=0.68) \text { and malformation } \\
(p=0.99) .\end{array}$ \\
\hline Paper 12 [33] & $\begin{array}{l}\text { Mothers of children hospitalized } \\
\text { with cancer: } 30\end{array}$ & $\begin{array}{l}\text { Mothers of children hospitalized } \\
\text { with cancer: } 30\end{array}$ & $\begin{array}{l}\text { (A) } \\
\text {-Inventory of Spielberger's State Anxiety. } \\
\text { (Data were collected at three times: before, after the intervention and } \\
21 \text { days after prayers had ended). } \\
\text { (I) } \\
\text {-The petition prayer was said three times a day for three weeks by the } \\
\text { participants, who were instructed to go to the religious temple/space in the } \\
\text { hospital to connect with God through prayer. }\end{array}$ & $\begin{array}{l}\text {-After the intervention the difference between the anxiety } \\
\text { averages in both groups was significant }(p=0.001) \text {; } \\
\text {-IG had significant reduction in anxiety (CG: } 58.93 \pm 9.8 \text { and IG } \\
40.96 \pm 12.4) \text {. } \\
\text {-No difference between the pre and post intervention groups } \\
(p=0.001) \text {. }\end{array}$ \\
\hline
\end{tabular}




\section{Discussion}

The concepts of religion and spirituality comprise different dimensions (affective, cognitive and behavioural), and prayer is considered an expression of the behavioural dimension [35].

Adults who are dealing with negative life issues and stressful situations often use prayer. Intercessory prayer was used more in this study than petition prayer, which is in harmony with previous research [28,36]. Using intercessory prayer in research could provide the researchers better conditions to control bias, as this type of research involving such subjective variables could be quite challenging. On the other hand, asking patients to pray, in case of using petition prayer, depends on patients' health conditions and this may arise ethical questions regarding the guarantee of the principle of justice. These may constitute important aspects to take into consideration when planning RCTSs using prayer, as there should be always the guarantee of respecting patients' beliefs and wishes.

The interest in research about prayer is recent, although it has been used in healing processes since ancient times. The literature highlights that in both the twentieth century and the twenty-first century there has been growing interest in examining the effect of prayer on diseases or health disturbances such as anxiety, depression, stress and heart disease [24,28,37,38].

The literature suggests that prayer is recognised as a complementary intervention or alternative therapy identified by healthcare professionals as adequate treatment for religious/spiritual disturbances or concerns, because patients considered it significant when it was used [39]. In a holistic paradigm and patient centered care all patients' dimensions should be considered and all needs should be addressed, and this is often included in professional ethical codes and main health policies. Even when physicians or nurses (as those that are more in contact with the patients) feel they are unprepared to pray with patients, the presence of religious leaders or chaplains should be requested as they are member of the multidisciplinary healthcare team. The results of this review show that the use of prayer, whether petition or intercessory, in clinical practice may promote different positive effects such as the reduction of anxiety and depression; a higher implantation rate for successful and multiple pregnancies; better physical functioning; fewer deaths in patients with bloodstream infections; fewer days in the Coronary Care Unit for patients with cardiac problems. Considering that prayer is a non-pharmacological intervention, these results arise questions regarding health economy, and thus more research is needed in order to identify the economic outcomes when implementing this kind of interventions in regard of the sustainability of the healthcare systems. But the implementation of prayer as an intervention should be based in training, as this includes dealing with patients' intimacy, values and beliefs.

It should be noted with regard to the practice of prayer, particularly intercessory prayer, that each study used a different frequency, duration and assessment method. Most of the 10 studies applied prayer over a period of time of less than one month [23,25-28,30,33,34] and on a daily basis [23,24,26-28,32,34]. Most studies used assessment tools [24,26,32,34]. These differences may reinforce the argument that positive findings and more accurate studies and evidence are jeopardized. This means there is a need to standardise interventions to minimise methodological limitations in future studies about prayer [40].

According to the Jadad criteria used to assess the methodological accuracy of clinical trials, the studies that scored three or higher in this review were considered to show positive results in terms of the effect of prayer on health, and so they could be considered reliable and having methodological consistency. This is an important aspect because clinical trials determine and evaluate the effectiveness of new therapies and interventions [41] and seems to be an adequate method to further research looking for the effect of prayer.

\section{Conclusions}

Different therapies and interventions have been developed to help patients to cope when dealing with health problems. Prayer is an activity that is widely used and investigated as a therapeutic and adequate intervention in healthcare. However, more evidence is needed regarding positive health 
outcomes for it to be effectively implemented as such, through studies that have good methodological accuracy. This review only included RCTs and did not include grey literature, and this may constitute a publication bias that should be considered when analysing the results, as the search that was limited to the title as well.

Consistency in the results was found and prayer, whether petition or intercessory, seems to help patients to cope in times of illness and crisis. This conclusion underlines the need to conduct research that seeks to further evaluate the benefits of prayer on patients' health. It also emphasizes the importance of the integration of prayer in clinical practice, according to the patients and professionals' boundaries and competencies, aiming for effective holistic care. Healthcare professionals should consider patients' spirituality and religious needs and need to be prepared to provide that support. This highlight the need for education and training based on an ethical background that is paramount when dealing with religiosity or spirituality. Healthcare teams should consider prayer as an intervention, as this is an example of the holistic paradigm in health and the effects of such an intervention should be considered in a multidisciplinary and patient-centered approach.

Author Contributions: Talita Prado Simão, Sílvia Caldeira, and Emilia Campos de Carvalho conceived and designed the review, analysed the data, and wrote the paper.

Conflicts of Interest: The authors declare no conflict of interest.

\section{Abbreviations}

The following abbreviations are used in this manuscript:

$\begin{array}{ll}\text { IG } & \text { Intervention Group } \\ \text { IVF } & \text { In vitro Fertilisation } \\ \text { CG } & \text { Control Group } \\ \text { CCU } & \text { Coronary Care Unit } \\ \text { RCT } & \text { Randomized Clinical Trials } \\ \text { WHO } & \text { World Health Organization }\end{array}$

\section{References}

1. World Health Organization. WHOQOL and Spirituality, Religiousness and Personal Beliefs (SRPB). Geneva: World Health Organization, 1998.

2. Moacyr Scliar. "História do Conceito de saúde." Revista Saúde Coletiva 17 (2007): 29-41. [CrossRef]

3. Ramon Moraes Penha, and Maria Júlia Paes da Silva. "Meaning of spirituality for critical care nursing." Texto Contexto Enfermagem 21 (2012): 260-68. [CrossRef]

4. Rogério Rodrigues da Silva, and Deis Siqueira. "Spirituality, religion and work in the organizational context." Psicologia em Estudo 14 (2009): 557-64. [CrossRef]

5. Nilvete Soares Gomes, Marianne Farina, and Cristiano Dal Forno. “Espiritualidade, Religiosidade e Religião: Reflexão de Conceitos em Artigos Psicológicos." Revista de Psicologia da IMED 6 (2014): 107-12. [CrossRef]

6. Heather S. L. Jim, James E. Pustejovsky, Crystal L. Park, Suzanne C. Danhauer, Allen C. Sherman, George Fitchett, Thomas V. Merluzzi, Alexis R. Munoz, Login George, Mallory A. Snyder, and et al. "Religion, Spirituality, and Physical Health in Cancer Patients: A Meta-Analysis." Cancer 121 (2015): 3760-68. [CrossRef] [PubMed]

7. Raquel G. Panzini, and Denise R. Bandeira. “Spiritual/religious coping." Revista Psiquiatria Clínica 34 (2007): 126-35. [CrossRef]

8. João P. Cabral. “A prece revisitada: Comemorando a obra inacabada de Marcel Mauss." Religião e Sociedade 29 (2009): 13-28.

9. Jaqueline Lopes, Mônica R. Lira, Gina A. Abdala, and Alberto M. S. Oliveira. "O impacto da reabilitação aquática associada à oração no desempenho funcional de pacientes pós-acidente vascular encefálico." Saúde Coletiva 37 (2010): 9-14.

10. Silvia Caldeira. “Cuidado espiritual-rezar como intervenção de enfermagem." CuidArteEnfermagem 3 (2009): 157-64. 
11. Mary Rute G. Esperandio, and Kevin L. Ladd. "I Heard the Voice. I Felt the Presence: Prayer, Health and Implications for Clinical Practice." Religions 6 (2015): 670-85. [CrossRef]

12. Tosta Carlos Eduardo. “Does prayer heal?" Brasília Médica 34 (2004): 38-45.

13. Kevin L. Ladd, and Bernard Spilka. "Prayer: A Review of the empirical literature." In APA Handbook of Psychology, Religion, and Spirituality. Washington: American Psychological Association, 2013, vol. 1, pp. 293-307.

14. Hélio P. Guimarães, and Álvaro Avezum. "O impacto da espiritualidade na saúde física." Revista Psiquiatria Clínica 34 (2007): 88-94. [CrossRef]

15. Judith M. Wilkinson, and Karen van Leuven. "Fundamentos de Enfermagem: Teoria, Conceitos e Aplicações." Avaiable online: http://www.livronauta.com.br/ livro-Judith_M_Wilkinson_Karen_Van _Leuven-Fundamentos_de_Enfermagem_Teoria_Conceitos_e_Aplicacoes_2_Volumes-Roca-Sebo_Releitur as_Portao-Curitiba-22954770 (accessed on 18 January 2016).

16. Camila C. Carvalho, Erika C. L. Chaves, Denise H. Iunes, Talita P. Simão, Cristiane S. M. Grasselli, and Cristiane G. Braga. "The effectiveness of prayer in reducing anxiety in cancer patients." Revista da Escola de Enfermagem da USP 48 (2014): 683-89. [CrossRef]

17. Leoni Zenevicz, Yukio Moriguchi, and Valéria S. Faganello Madureira. "The religiosity in the process of living getting old." Revista da Escola de Enfermagem da USP 47 (2013): 433-39. [CrossRef]

18. Ian N. Olver, and Andrew Dutney. "A Randomized, Blinded Study of the Impact of Intercessory Prayer on Spiritual Well-being in Patients With Cancer." Alternative Therapies 18 (2012): 18-27.

19. David Evans. "Systematic reviews of nursing research." Intensive and Critical Care Nursing 17 (2001): 51-57. [CrossRef] [PubMed]

20. Joanna Briggs Institute. Reviewers' Manual. Adelaide: Joanna Briggs Institute, 2014.

21. Cristina M. C. Santos, Cibele A. M. Pimenta, and Moacyr R. C. Nobre. "The pico strategy for the research question construction and evidence search." Revista Latino-Americana de Enfermagem 15 (2007): 508-11. [CrossRef]

22. Alejandro R. Jadad, Andrew R. Moore, Dawn Carroll, Crispin Jenkinson, John D. Reynolds, David J. Gavaghan, and Henry J. McQuayj. “Assesing the Quality of Reports of randomized Clinical Trials: Is Blinding Necessary? " Controlled Clinical Trials 17 (1996): 1-12. [CrossRef]

23. John A. Astin, Jerome Stone, Donald I. Abrams, Dan H. Moore, Paul Couey, Raymond Buscemi, and Elisabeth Targ. "The efficacy of distant healing for human immunodeficiency virus-Results of a randomized trial." Alternative Therapies 12 (2006): 36-42.

24. Peter A. Boelens, Roy R. Reeves, William H. Replogle, and Harold G. Koenig. "A randomized trial of the effect of prayer on depression and anxiety." The International Journal of Psychiatry in Medicine 39 (2009): 377-92. [CrossRef] [PubMed]

25. Mitchell W Krucoff, Suzanne W Crater, Dianne Gallup, James C Blankenship, Michael Cuffe, Mimi Guarneri, Richard A Krieger, Vib R Kshettry, Kenneth Morris, Mehmet Oz, and et al. "Music, imagery, touch, and prayer as adjuncts to interventional cardiac care: The Monitoring and Actualisation of Noetic Trainings (MANTRA) II randomised study." Lancet 36 (2005): 211-17.

26. Raymond F. Palmer, David Katerndahl, and Jayne Morgan-Kidd. "A Randomized Trial of the Effects of Remote Intercessory Prayer: Interactions with Personal Beliefs on Problem-Specific Outcomes and Functional Status." The Journal of Alternative and Complementary Medicine 10 (2004): 438-48. [CrossRef] [PubMed]

27. Herbert Benson, Jeffery A. Dusek, Jane B. Sherwood, Peter Lam, Charles F. Bethea, William Carpenter, Sidney Levitsky, Peter C. Hill, Donald W. Clem Jr., Manoj K. Jain, and et al. "Study of the Therapeutic Effects of Intercessory Prayer (STEP) in cardiac bypass patients: A multicenter randomized trial of uncertainty and certainty of receiving intercessory prayer." American Heart Journal 151 (2006): 934-42. [CrossRef]

28. William S. Harris, Manohar Gowda, Jerry W. Kolb, Christopher P. Strychacz, James L. Vacek, Philip G. Jones, Alan Forker, James H. O'Keefe, and Ben D. McCallister. "A randomized controlled trial of the effects of remote intercessory prayer on outcomes in patients admitted to the coronary care unit." Archives International Medicine 159 (1999): 2273-78. [CrossRef]

29. Jennifer M. Aviles, Ellen Whelan, Debra A. Hernke, Brent A. Williams, Kathleen E. Kenny, Michael O’ Fallon, and Stephen L. Kopecky. "Intercessory prayer and cardiovascular disease progression in a coronary care unit population: A randomized controlled trial." Mayo Clinic Proceedings 76 (2001): 1192-98. [CrossRef] [PubMed] 
30. Kwang Y. Cha, Daniel P. Wirth, and Rogerio A. Lobo. “Does Prayer Influence the Success of in Vitro Fertilization-Embryo Transfer? Report of a Masked, Randomized Trial." Journal of Reproductive Medicine 46 (2001): 781-87. [PubMed]

31. Leonard Leibovici. "Effects of remote, retroactive intercessory prayer on outcomes in patients with bloodstream infection: Randomised controlled trial." British Medical Journal 323 (2001): 1450-51. [CrossRef] [PubMed]

32. C. R. Joyce, and R. M. Welldon. “The objective efficacy of prayer: A double-blind clinical trial." Journal of Chronic Diseases 18 (1965): 367-77. [CrossRef]

33. Maria I. Rosa, Fabio R. Silva, Bruno R. Silva, Luciana C. Costa, Angela M. Bergamo, Napoleão C. Silva, Lidia R. F. Medeiros, Iara D. E. Battisti, and Rafael Azevedo. "A randomized clinical trial on the effects of remote intercessory prayer in the adverse outcomes of pregnancies." Ciência Eamp; Saúde Coletiva 18 (2013): 2379-84. [CrossRef]

34. K. H. Dehghani, A. Zare Rahimabadi, Z. Pourmovahed, H. Dehghani, A. Zarezadeh, and Z. Namjou. "The Effect of Prayer on Level of Anxiety in Mothers of Children with Cancer." Iranian Journal of Pediatric Hematology Oncology 12 (2012): 1-6.

35. John M. Salsman George Fitchett, Thomas V. Merluzzi, Allen C. Sherman, and Crystal L. Park. "Religion, spirituality, and health outcomes in cancer: A case for a metaanalytic investigation." Cancer 121 (2015): 3754-59.

36. John A. Astin, Elaine Harkness, and Edzar Ernst. "The efficacy of distant healing: A systematic review of randomized trials." Annals of Internal Medicine 6 (2000): 903-10. [CrossRef]

37. David Brain Wolf. "Effects of the Hare Krsna Maha Mantra on Stress, Depression and the Three Gunas." Ph.D. Thesis, Florida State University, Tallahassee, FL, USA, 1999.

38. Kuciano Bernardi, Peter Sleight, Gabriele Bandinelli, Simone Cencetti, Lamberto Fattorini, Johanna Wdowczyc-Szulc, and Afonso Lagi. "Effect of rosary prayer and yoga mantras on autonomic cardiovascular rhythms: Comparative study." BMJ 323 (2001): 1446-49.

39. Suzette Brémault-Phillips, Joanne Olson, Pamela Brett-MacLean, Doreen Oneschuk, Shane Sinclair, Ralph Magnus, Jeanne Wei, Marjan Abbasi, Jasneet Parmar, and Christina M. Puchalski. “Integrating Spirituality as a Key Component of Patient Care." Religions 6 (2015): 476-98. [CrossRef]

40. Maria Inês Rosa, Fábio R. Silva, and Napoleão C. Silva. "A oração intercessória no alívio de doenças." Arquivos Catarinenses de Medicina 36 (2007): 103-8.

41. Teresa C. Camargo. "The role of the nurse participation in clinical trials: A review of the literature." Revista Brasileira de Cancerologia 48 (2002): 569-76.

(C) 2016 by the authors; licensee MDPI, Basel, Switzerland. This article is an open access article distributed under the terms and conditions of the Creative Commons by Attribution (CC-BY) license (http://creativecommons.org/licenses/by/4.0/). 